\author{
В.А. Білецька, Н.С. Яцечко
}

Днепропетровский национальный университет імені Олеся Гончара

\title{
ВИВЧЕННЯ ПРОЦЕСІВ ТРАНСФОРМАЦІї ВОДОРОЗЧИННИХ ФОРМ ВАЖКИХ МЕТАЛІВ ПРИ ДЕТОКСИКАЦІї ЗОЛИ СМІТТЕСПАЛЮВАЛЬНОГО ЗАВОДУ
}

\footnotetext{
Проведено комплексні дослідження процесів трансформації водорозчинних форм важких металів при взаємодії осадових порід із золою. Доведено, що процеси сорбційної іммобілізації приводять до суттєвого зниження вмісту міграційноздатних форм важких металів у відходах.
}

Ключові слова: зола, детоксикація, важкі метали, осадові породи.

Проведены комплексные исследования процессов трансформации водорастворимых форм тяжелых металлов при взаимодействии осадочных пород с золой. Доказано, что процессы сорбционной иммобилизации приводят к существенному снижению содержания миграционноспособных форм тяжелых металлов в отходах.

Ключевые слова: зола, детоксикация, тяжелые металлы, осадочные породы.

The complex research processes of transformation of soluble forms of heavy metals in sediment interaction with ash. Proved that the adsorption processes of immobilization lead to a significant decrease of soluble forms of heavy metals in the waste.

Key words: ash, detoxification, heavy metals, sedimentary rock.

Вступ. Необхідність своєчасного знешкодження та утилізації промислових та побутових відходів $є$ у теперішній час однією 3 найбільш злободенних проблем геоекології і охорони навколишнього середовища від їх негативного впливу. На теперішній час в Україні площа звалищ перевищує 150 тис. га, на яких щорічно нагромаджуються до 1 млрд т твердих відходів. 3 них кількість побутових відходів становить більш 12 млн т на рік і щорічний їх приріст складає майже $2 \%$ [1,2].

У проблемі складування та поховання відходів $є$ актуальні питання, які необхідно вирішити для поліпшення екологічної безпеки та забезпечення сталого розвитку країни: достовірна оцінка ступеню токсичності відходів, їх детоксикація та утилізація.

Постановка проблеми. Екотоксикологічна оцінка хімічного складу золи сміттєспалювального заводу м. Дніпропетровська показала, що у золі присутній значний спектр високотоксичних неорганічних речовин, в тому числі важких металів, кількість яких досягає 30. При цьому переважають найбільш токсичні метали (І клас токсичності), частка їх складає від $40 \%$ до 80 \%. Тому цей продукт термічної переробки побутових відходів становить безпосередню загрозу для довкілля. та потребує проведення детоксикації. Детоксикація відходів - це процес, який призводить до зниження токсичності відходів за рахунок зменшення в них вмісту токсичних компонентів.

Метою роботи $є$ проведення детоксикації золи за рахунок зниження міграційної здатності водорозчинних форм важких металів і відповідно ступеню токсичності відходів. Дослідження процесу детоксикації включали: вибір матеріалу, який забезпечить можливість їх незворотного зв'язування у сполуки за рахунок переходу рухомих форм металів у нерухомі; визначення ступеню небезпеки золи після іiі детоксикації; оцінку ефективності процесу детоксикації. 
Викладення основного матеріалу. У основу рішення поставленої проблеми покладена концепція зв'язування важких металів, які знаходяться у відходах, природними дисперсними матеріалами - осадовими породами.

Експерименти з лабораторного моделювання процесів детоксикації золи за рахунок трансформації геохімічних форм важких металів виконувалися за наступною методикою: наважки золи та осадової породи у заданому співвідношенні переносили до фарфорової чашки та ретельно перемішували речовини у сухому стані. Після чого добавляли від 4 до 10 дм $^{3}$ дистильованої води (залежно від кількості суміші), добре перемішували суміш з метою зволоження, обмивали рештки речовин зі скляної палички ще 2 дм $^{3}$ дистильованої води, прикривали чашки фільтрувальним папером та залишали зразки до повного висихання суміші.

Висушені зразки суміші уявляли собою зцементовану масу, тому іiі подрібнювали i розтирали у фарфоровій чашці скляною паличкою, а потім змістовне переносили до конічної колби, куди додавали необхідний об'єм дистильованої води для приготування водної витяжки за стандартною методикою [3].

Ефективність процесу детоксикації золи 3 використанням природних сорбентів оцінювалась за двома показниками: зміною вмісту водорозчинних форм важких металів у відходах після їх взаємодії з природними сорбентами та ступенем детоксикації відходів.

Слід відзначити, що у запропонованому способі зниження токсичності золи відбувається за рахунок двох факторів: по-перше, внаслідок прояву сорбційних властивостей природного дисперсного матеріалу відбувається трансформація водорозчинних форм важких металів у нерухомі, по-друге, внаслідок розведення токсичної золи екологічно безпечним природним матеріалом зменшується відносний вміст важких металів у кінцевому продукті - суміші.

Сумісний вклад цих факторів оцінювали за формулою:

$$
\omega=\frac{C_{0}-C_{\mathrm{K}}}{C_{0}},
$$

де $\omega$ - ступінь детоксикації;

$C_{0}$ - вміст важкого металу у золі (шлаку) до детоксикації, мг/г;

$\mathrm{C}_{\mathrm{k}}$ - вміст важкого металу у суміші після детоксикації, мг/г.

За цією формулою проводився розрахунок ступеню детоксикації золи 3 використанням природних сорбентів щодо водорозчинних форм кожного з восьми металів (свинцю, міді, марганцю, цинку, хрому, кадмію, кобальту, нікелю), що містяться у золі.

Комплексні дослідження 3 вивчення трансформації міграційноздатних водорозчинних форм важких металів при взаємодії осадових порід із золою показали, що при використанні як сорбенту некарбонатної глини відбувається процес трансформації до міцнозв'язаних форм практично усіх досліджених важких металів.

Оцінка зміни вмісту водорозчинних форм важких металів у золі також свідчить про перевагу некарбонатної глини як сорбенту над карбонатними осадовими породами. Найбільш суттєво ця перевага проявляється у процесі детоксикації золи щодо водорозчинних форм міді та марганцю. Якщо карбонатними породами ці метали у водорозчинній формі не поглинаються зовсім, 
то застосування в якості сорбенту глини некарбонатної більш, ніж наполовину знижує вміст водорозчинних форм міді та марганцю у золі.

Процес детоксикації золи щодо водорозчинних форм кадмію, кобальту та хрому також більш повно відбувався при використанні як сорбенту глини некарбонатної (максимальна ступінь детоксикації для цих металів становила відповідно - 54\%, 33\% та 69\%). Застосування карбонатних порід характеризувалося набагато нижчими величинами максимального ступеню детоксикації золи - $20 \%$ для кадмію, $17 \%$ для кобальту та хрому.

Водорозчинні форми свинцю із золи найбільш повно поглинаються також некарбонатної глиною (62\%). Використання для детоксикації золи карбонатних порід є значно менш ефективним, оскільки максимальний ступінь детоксикації золи щодо свинцю при застосуванні як сорбенту лесу та карбонатної глини не перевищує $45 \%$, суглинку - навіть $30 \%$.

На відміну від інших досліджених важких металів, процес трансформації водорозчинних форм цинку та нікелю у золі відбувається значно ефективніше при використанні в якості сорбенту саме карбонатних порід. Особливо це $є$ характерним для нікелю, максимальний ступінь детоксикації золи для нього склав при застосуванні суглинку $-37 \%$, лесу $-51 \%$ та карбонатної глини $-57 \%$. Для порівняння - використання глини некарбонатної дозволило знизити вміст водорозчинних форм нікелю у золі лише на $26 \%$. Суглинок, лес та карбонатна глина проявили однакову здатність до поглинання водорозчинного цинку із золи при максимальному ступені детоксикації 65\%. Поглинальна здатність некарбонатної глини щодо цинку у водорозчинній формі є на $20 \%$ меншою.

Таким чином, за своєю здатністю переходити 3 водорозчинних до міцнозв'язаних форм у процесі детоксикації золи з використанням природних сорбентів - осадових порід важкі метали можна розташувати у наступний ряд:

$$
\mathrm{Cr}>\mathrm{Zn}>\mathrm{Pb}>\mathrm{Ni}>\mathrm{Cu}>\mathrm{Co}>\mathrm{Mn}>\mathrm{Cd} \text {. }
$$

Висновки. Доведено, що дисперсні матеріали класу алюмосилікатів мають високі сорбційні властивості щодо важких металів, які присутні у золі. Визначено, що ступінь іммобілізації важких металів підвищується зі зростанням загального вмісту кожного 3 них і обмежується величиною граничної ємності поглинання сорбенту. Дослідження процесу детоксикації продуктів термічної переробки твердих відходів з використанням природних матеріалів показали, що різні породи мають неоднакові поглинальні властивості щодо певних металів. Тому питання вибору порід-сорбентів повинно вирішуватися з урахуванням хімічного складу продуктів, що підлягають детоксикації.

\section{Бібліографічні посилання}

1. Суматохіна, I.M. Промислові відходи як чинник стану екологічної безпеки регіону: оцінка, картографія, управління / I.M. Суматохіна, Н.M. Дук, О.А. Шевченко // Екологія довкілля та безпека життєдіяльності. - К., 2008. -№1. C. $69-75$.

2. Сметакин, А.И. Защита окружающей среды от отходов производства и потребления: уч. пособие для студ. ВУЗов / А.И. Сметакин. - К., 2000. - 134 с.

3. Аринушкина, Е. В. Руководство по химическому анализу почв / Е. В. Аринушкина. - М.: Изд-во МГУ, 1970. - 487 с.

Надійшла до редколегії 17.04.11. 